\title{
Using concept maps to structure a small-scale literature review: an approach to research-based learning in pre-service teacher education
}

\author{
El empleo de mapas conceptuales para estructurar una revisión de literatura de \\ pequeña escala: una aproximación al aprendizaje basado en investigación en la \\ formación inicial de maestros
}

Utilitzant mapes conceptuals per a estructurar una revisió de literatura a petita escala: una aproximació a l'aprenentatge basat en la investigació en la formació inicial de mestres

\author{
Victoria I. Marín*(ఠ) \\ Departament de Pedagogia, Universitat de Lleida, Lleida, Spain \\ *Corresponding author: victoria.marin@udl.cat (Victoria I. Marín)
}

Received: 02/22/2021 | Accepted: 04/13/2021 | Published: 07/19/2021

Citation: Marín, V. I. (2021). Using concept maps to structure a small-scale literature review: an approach to research-based learning in pre-service teacher education. Research in Education and Learning Innovation Archives, 27,1-18. 10.7203/realia.27.20492

Copyright: The Authors. Open Access: This article is distributed under the terms of the Creative Commons Attribution-NoDerivatives 4.0 International licence (CC BY-ND 4.0)

Funding: This work was supported by the Quality Pact for Teaching of the Federal Ministry of Education and Research (BMBF) of Germany under Grant 01PL16056 Research-Based Learning in Focus Plus (FLiF+) project [Forschungbasiertes Lernen im Fokus Plus - FliF plus], University of Oldenburg
ABSTRACT: Research-based learning (RBL) is a useful tool for combining theory and practice in teacher education. However, pre-service teachers struggle with the idea of teacher as researcher. One popular (meta)methodology considered in educational research (and that is well suited to school research) is design-based research (DBR). Incorporating this approach into RBL as a method for developing teaching innovation in schools could be one way to include RBL in teacher education and place pre-service teachers in the position of teacher as researcher. This study explores the potential of using digital concept maps to support the conceptualization phase (during the literature review) of an RBL process based on DBR in a pre-service teacher-education course prior to the design of a teaching innovation strategy for schools. Quantitative and qualitative data were obtained from a questionnaire administered to pre-service teachers and from the semantic evaluation of the concept maps of these teachers. Our results show an overall consensus among pre-service teachers that concept maps are useful for structuring small-scale literature reviews. Pre-service teachers also believe there is a strong possibility that they will use concept maps when they become teachers. We use our findings to make recommendations for university lecturers to use digital concept maps to design RBL activities based on literature reviews and with emphasis on teacher education.

KEYWORDS: research-based learning; pre-service teacher training; digital concept mapping; designbased research; higher education

RESUMEN: El aprendizaje basado en la investigación (ABI) se considera una herramienta útil para integrar la teoría y la práctica en la formación de maestros. Sin embargo, los maestros en formación se enfrentan a la idea poco clara del profesor como investigador. Una de las (meta)metodologías populares consideradas en la investigación educativa, que se adapta bien a la investigación escolar, es la investigación basada en el diseño (IBD). La incorporación de este enfoque en el ABI como forma de desarrollar innovaciones pedagógicas en las escuelas puede ser una opción para integrar el $\mathrm{ABI}$ en la formación de maestros y poner a los maestros en formación en el lugar del profesor como investigador. Este estudio explora el potencial de los mapas conceptuales digitales para apoyar el 
desarrollo de la fase de conceptualización -durante la revisión de la literatura- de un proceso de ABI basado en una perspectiva de IBD en una asignatura de formación inicial de maestros, como fase previa al diseño de una innovación docente para escuelas. Se obtuvieron datos cuantitativos y cualitativos a partir de un cuestionario para maestros en formación y de la evaluación semántica de sus mapas conceptuales. Los resultados muestran un consenso general entre los maestros en formación respecto a que los mapas conceptuales son realmente útiles para estructurar revisiones bibliográficas a pequeña escala y tienen un marcado potencial para ser utilizados cuando se conviertan en maestros. De los resultados se derivan recomendaciones para que los profesores universitarios diseñen actividades de $\mathrm{ABI}$ relacionadas con revisiones bibliográficas utilizando mapas conceptuales digitales, con énfasis en la formación de maestros.

PALABRAS CLAVE: aprendizaje basado en la investigación; formación inicial de maestros; mapas conceptuales; investigación basada en diseño; educación superior

RESUM: L'aprenentatge basat en la investigació ( $\mathrm{ABI}$ ) es considera una eina útil per a integrar la teoria i la pràctica en la formació de mestres. No obstant això, els mestres en formació s'enfronten a la idea poc clara del professor com a investigador. Una de les (meta) metodologies populars considerades en la investigació educativa que s'adapta bé a la investigació escolar és la recerca basada en el disseny (RBD). La incorporació d'aquest enfocament en l'ABI com a forma de desenvolupar innovacions pedagògiques a les escoles pot ser una opció per a integrar l'ABI en la formació de mestres i de posar els mestres en formació en el lloc del professor com a investigador. Aquest estudi explora el potencial dels mapes conceptuals digitals per a donar suport al desenvolupament de la fase de conceptualització -durant la revisió de la literatura- d'un procés d'ABI basat en una perspectiva de RBD en una assignatura de formació inicial de mestres, com a fase prèvia al disseny d'una innovació docent per a escoles. Es van obtenir dades quantitatives i qualitatives a partir d'un qüestionari per a mestres en formació i de l'avaluació semàntica dels seus mapes conceptuals. Els resultats mostren un consens general entre els mestres en formació respecte al fet que els mapes conceptuals són realment útils per a estructurar revisions bibliogràfiques a petita escala i tenen un marcat potencial per a ser utilitzats quan es convertisquen en mestres. Dels resultats es deriven recomanacions perquè els professors universitaris dissenyen activitats d'ABI relacionades amb revisions bibliogràfiques utilitzant mapes conceptuals digitals, amb èmfasi en la formació de mestres.

PARAULES CLAU: aprenentatge basat en la investigació; formació inicial de mestres; mapes conceptuals; investigació basada en disseny; educació superior

\section{Practitioner Notes}

\section{What is already known about this topic}

- Research-based learning is a useful teaching methodology to integrate theory and practice in teacher education.

- Conducting a literature search on a research topic is one of the possible research-based learning typologies.

- Concept mapping is a popular constructivist-based tool, whose positive impact in higher education and teacher education has been clearly demonstrated over the years.

\section{What this paper adds}

- Introduces and explores the use of (digital) concept maps for research-based learning in teacher education, concretely for developing the outline of a literature review.

- Pre-service teachers valued the use of digital concept maps as a tool for supporting a small-scale literature review.

- Offers recommendations for university educators to support a literature review with (digital) concept maps in pre-service teacher education.

\section{Implications for practice and/or policy}

- Need for supporting pre-service teachers before, during and after the RBL activity in terms of using (digital) concept maps, considering the literature review and defining the research question.

- Emphasis should be put on connecting theory and practice, going from the literature review reflected in the map to the designed educational practice. 


\section{INTRODUCTION AND REVIEW OF THE LITERATURE}

One of the possible approaches to enhancing the professionalism of pre-service teachers in higher education is the 'explicit integration of research and research-based learning in curricular frameworks' (Saunders, 2017, 3). Research-based learning (RBL) is defined as a set of teaching and learning approaches in which students actively engage in research activities such as problem-based learning or project-based learning (Rijst, 2017). In teacher education programmes, RBL may help pre-service teachers to integrate theory and practice, which may result in more successful classroom practice. In addition, RBL can complement training activities that develop flexibility and agency, as well as a critical and reflective mindset (Saunders, 2017), which are important foundations for educational practitioners. However, the basis for RBL in education (educational research) and its role in teacher education are still debated and a range of mixed views on the subject are present, as Brew and Saunders (2020) point out. This calls into question the purposes and goals of RBL within teacher education programmes.

Future teachers, as drivers of change in education, are expected to design new scenarios in which educational goals can be achieved (Mor \& Mogilevsky, 2013, 2013 b). Hence, as one of the common approaches to educational research, design-based research (DBR) may offer a way for teachers to engage in educational innovation (de Benito \& Salinas, 2016; Easterday, Lewis, \& Gerber, 2018; Reinmann, 2018), implying that this method could be integrated into a RBL approach in teacher education programmes.

Additionally, RBL involves self-directed and productive learning as characteristics of learning within the paradigm of constructivism. This type of learning is complemented by the use of digital tools (Marín, 2020a). Although there are not many examples of linking RBL with digital tools in the literature, the author has been involved in various developments in this area over the last years, both in university faculty training (Marín, 2019; Marín \& Schirmer, 2018) and with university-level students (Marín, 2020a). One of the highlighted and multifaceted tools that can be used to support RBL is digital concept maps (Marín, 2019), since they clearly relate to the constructivist aspects of learning that are also connected to RBL (Marín, 2020a). Although concept mapping has been covered in the literature in the context of higher education (Kinchin, 2014) and in teacher education (Koc, 2012), little is known about its use in a RBL context.

Therefore, this study explores how one of the first RBL phases in pre-service teacher education, namely the conceptualisation phase of a literature review, can be enhanced by the use of (digital) concept maps. With that aim in mind, an RBL learning activity using concept maps in a teacher education course was designed, implemented and evaluated according to a DBR perspective. The conclusion of this article includes recommendations and guidelines for university educators to design similar learning interventions in pre-service teacher education.

\subsection{Research-based learning in teacher education}

According to Saunders $(2017,4)$, research-based learning is "an academic means to help further long-term professionalization of future teachers" by helping pre-service teachers to integrate theory and practice. However, pre-service teachers argue that "there is an unclear idea of teachers as researchers [...] and [they] struggle to connect the theory-oriented education in their studies with teaching practice in schools" (Brew and Saunders, 20202 ) Furthermore, the same authors found that different ideas about research-based learning exist among teacher trainers.

Although other methods for training teachers as researchers might be considered, DBR is commonly used to develop, implement and evaluate different kinds of procedures or products that aim to solve an educational problem, or address a particular 
educational situation (Aditomo, Goodyear, Bliuc, \& Ellis, 2013; de Benito \& Salinas, 2016). As the latter authors explain, educational products may consist of educational materials, lesson plans, online courses, or pedagogical strategies, among others. DBR combines empirical educational research with a theory-driven design of learning scenarios and environments, thus promoting educational innovation (The-Design-BasedResearch-Collective, 2003). Furthermore, DBR is considered a meta-methodology, consisting of different design process phases - focus, understand, define, conceive, build, test and present - that recursively nest other research processes and are applied in an iterative way (Easterday et al., 2018).

Based on the conception of DBR as a meta-methodology, it is possible to incorporate different research methodologies into the design of the various phases. For instance, the second phase - 'understanding' - 'investigates the problem through empirical methods and secondary sources and synthesizes that knowledge into a form that can be easily used later' (Easterday et al., 2018, 139). Therefore, one of the possible scientific processes within this phase is a literature review. Rueß, Gess, and Deicke (2016)agree that conducting a literature search on a research topic is one of the possible RBL typologies. They describe a literature review as putting the emphasis on learning by research in terms of the level of students' activity, focusing on research results.

Considering the general steps for RBL proposed by Marín (2019) (see Table 1), a literature review could be considered a RBL activity in the conceptualisation phase of a research project. Note that although this process is shown in Table 1 as linear, it may also be considered as cyclical.

Table 1. RBL general steps and their description (Marín, 2019).

\begin{tabular}{ll}
\hline RBL general steps & Description \\
\hline 1. Orientation & $\begin{array}{l}\text { Aims to stimulate curiosity about a topic and address a learning } \\
\text { challenge through a problem statement }\end{array}$ \\
2. Conceptualisation & $\begin{array}{l}\text { Explores the related literature and involves the generation of research } \\
\text { questions and/or hypotheses }\end{array}$ \\
3. Investigation & $\begin{array}{l}\text { Includes the selection of methods and development of the research } \\
\text { design, obtaining data related to the research question, or }\end{array}$ \\
& $\begin{array}{l}\text { Draws conclusions from the data in relation to the hypotheses or } \\
\text { research questions }\end{array}$ \\
5. Conclusion & Presents and discusses the results through a communication process, \\
& and reflects on the results and the research process as a whole
\end{tabular}

This study stems from the need for pre-service teachers to develop a basic understanding of educational research as a first step in allowing them, as future teachers, to become drivers of educational innovation and change. Therefore, we focus on the RBL activity of a literature review conducted in the context of pre-service teacher education.

\subsection{Concept mapping in higher education and teacher education}

The concept mapping method is based on Ausubel's assimilation theory of learning and constructivism theory, and was invented by Novak in 1972 (Novak \& Cañas, 2008). Both these learning theories assume that students have existent cognitive structures which they build on in order to gain new knowledge and skills in an active way, hence the use of concept maps as "graphical tools for organizing and representing (existing and new) knowledge" (Novak and Cañas, 2008, 1). According to the same authors, the main elements of concept maps are concepts, relationships (linking phrases) and propositions. They present two further important features for the facilitation of critical thinking: a hierarchical structure - from the more general and inclusive concepts to 
the more specific concepts, as fundamental characteristic of meaningful learning and the inclusion of cross links - relationships or links between concepts in different parts of the concept map. Concept mapping is a powerful tool for the facilitation of meaningful learning and it "serves as a kind of template or scaffold to help to organize knowledge and to structure it, even though the structure must be built up piece by piece with small units of interacting concept and propositional frameworks" (Novak and Cañas, 2008, 7).

Concept mapping allows students to surface their prior knowledge and to integrate it with new knowledge (Kinchin, 2014), as well as to highlight changes and growth in their knowledge (Hay \& Kinchin, 2008). Although often used interchangeably with mind mapping, the two tools are completely distinct in terms of purpose, structure, level of abstraction, linking devices, linking words and language register (Davies, 2011). Whilst mind maps are aimed at rapid notetaking and brainstorming, by highlighting associations between topics or ideas in the form of pictures or words linked with lines or colours in a non-linear structure, concept maps focus on the relations between concepts in the form of boxes linked with arrows and relational phrases in a hierarchical structure (Davies, 2011). However, it is more relevant to stress that concept mapping is a powerful tool for promoting a greater level of reflection and more meaningful learning; hence, the tool is most useful when students are able to visualize their own personal understanding, and not merely to re-state rote learning (Kinchin, 2014). The same author also highlights the importance of the following aspects in order to realize the learning potential of higher education students using concept maps:

- Consider the nature of the curriculum in which the concept mapping activity will be embedded, in terms of the degree of freedom that the students are offered for developing the concept and structure.

- Use concept mapping as a learning tool rather than as an assessment tool, thus guiding the search for information.

- Combine concept mapping activities with other learning strategies, such as collaborative learning or feedback from the university instructors on the students' maps.

- Provide clear learning objectives for the concept mapping activity.

According to Kinchin (2014), the positive impact of concept mapping on student learning in higher education has been clearly demonstrated since the end of the 1990s. For instance, Berry and Chew (2008) report in their study that the group of students who created concept maps showed significantly improved performance in the final exam in the context of general psychology, compared to the group of students working only with student-generated questions. Nesbit and Adesope (2006) conclude in their metaanalysis across educational levels, subject areas and settings, that "in comparison with activities such as reading text passages, attending lectures, and participating in class discussions, concept mapping activities are more effective for attaining knowledge retention and transfer" (Nesbit and Adesope, 2006, 434).

There is also extensive literature on the use of concept mapping in teacher education. Koc (2012) describes several instances in which pre-service teachers successfully used concept maps for a variety of purposes, including as a data analysis tool, for instructional decision-making, as an instructional supplement, or as an assessment tool. Schaal (2010) identified the positive impact of concept maps on achievement and motivation when used as a complement to online lectures in human biology for preservice teachers. Other authors have identified the benefits of using concept maps for promoting reflective thinking among pre-service teachers (Beyerbach \& Smith, 1990; Buldu \& Buldu, 2010). In addition, concept mapping activities have been successfully 
implemented in schools (Kinchin, 2000; Prats \& Ferrer, 2012), which points to their pedagogical potential as an effective educational tool for future teachers.

While concept mapping has been explored as a research tool - as a method for data reduction, data collection, or for guiding observation (Darder, Pérez, \& Salinas, 2014), little is known regarding the way in which concept maps may be used for supporting an outline of a literature review, whether within RBL approaches, or in the context of teacher education. This is the focus area of this study.

\subsection{Digital tools for research-based learning: the case of digital concept mapping}

Despite the suitability of digital tools in supporting RBL (Marín, 2020a), this topic has not yet been broadly explored. In the field of university faculty training, Marín and Schirmer (2018) proposed a strategy for encouraging university instructors to use digital tools for RBL in their courses. The authors present different tools for varied purposes connected to RBL, such as pinboard tools, collaborative writing and annotation tools, mind mapping tools, and concept mapping tools.

In the context of a postgraduate in educational sciences, Marín (2020a) studied how group RBL processes could be supported by e-portfolios and how relevant group RBL processes enhanced student collaborative groups. The findings of this study show that the RBL processes of documentation, reflection and collaboration were enhanced in the student groups through the use of e-portfolios. Alongside e-portfolios, Marín (2019) proposed the idea that digital concept maps are a multifaceted tool that can support RBL processes. Furthermore, concept maps support the constructivist aspects of learning, which are related to the theoretical underpinnings of RBL (Marín, 2020a).

Although concept mapping can be done with a pen and paper, digital concept mapping software allows for several new possibilities, such as adding multimedia elements, including links and documents, creating nested concept maps, and modifying the concept map structure easily and quickly, among others. Therefore, the benefits of digital concept mapping over hand drawn concept maps lies in visualising "in a synergistic manner both structures of knowledge and information visualisation approaches" (Novak \& Cañas, 2006, 180). This means that linked information (text documents, weblinks, videos, among others) is associated to the nodes in a way that a smooth and easy navigation through it is enabled.

Further digital possibilities are becoming increasingly more available, such as asynchronous and synchronous collaboration through concept maps, or the integration of artificial intelligence systems (Novak \& Cañas, 2006). Many authors have been taking advantage of these innovations in educational research (Agudelo \& Salinas, 2015; de Benito, Lizana, \& Salinas, 2017; Lizana, Marín, Moreno, Paniza, \& Salinas, 2014; Nesbit \& Adesope, 2006). Various online concept mapping software tools are now available such as Mindomo (freemium) and IHMC Cmaptools (free).

From a technical point of view, IHMC Cmaptools (https://cmap.ihmc.us/) (from now on, Cmap) offers a cloud version, a desktop version for all operating systems, and an iPad version. Institutions are also able to download the CmapServer and have their own virtual place to store concept maps. From a pedagogical point of view, Cmap was originally designed for educational purposes and is based on the theoretical premise of both the assimilation theory of learning and constructivism. Regarding the practical possibilities of Cmap as digital concept mapping software, "(it) empowers users, individually or collaboratively, to represent their knowledge using concept maps, to link media resources to them, to share them with peers and colleagues, and to publish them" (Tergan and Keller, 2005, 3).

Cmap can be used for all the RBL phases previously described (Table 1). However, this study uses Cmap in only the first two RBL steps applied to a literature search (Table 2). 
Table 2. Using Cmap in the RBL steps applied to a literature search (Marin, 2019)

\begin{tabular}{ll}
\hline RBL steps applied to a literature search & Uses of Cmap \\
\hline 1. Orientation & $\begin{array}{l}\text { Brainstorming a topic (like a simple mind map function) } \\
\text { Supporting the development of a focus question or } \\
\text { problem statement }\end{array}$ \\
& $\begin{array}{l}\text { Summarising the main concepts and connections of the } \\
\text { 2. Conceptualisation }\end{array}$ \\
& literature review that relate to the focus question \\
\hline
\end{tabular}

\section{MATERIALS AND METHODS}

This study presents a course design for pre-service teacher education which explores the implementation of (digital) concept maps in an RBL approach, specifically for compiling literature reviews. The originality of this study lies in these concrete educational settings. The method was applied specifically within the frame of a first DBR learning activity to develop an overview of a small-scale literature review in educational research; the activity was supported by instructor feedback and peer feedback.

The main objective of the study was formulated as the following main research question: How can the conceptualisation phase (of a literature review) in an RBL process in pre-service teacher education be enhanced by using concept maps?

Additionally, the following research sub-questions were explored:

- What do pre-service teachers believe are the most valued uses of concept maps for literature reviews?

- How do pre-service teachers perceive the usability and know-how transfer of concept maps?

- What is the level of semantic quality in pre-service teachers' concept maps for their literature reviews?

\subsection{Settings and participants}

The context of this study was a face-to-face pre-service teacher education course that took place in face-to-face settings at a German university. The purposeful sample comprised ten undergraduate pre-service teachers (six females and four males) following curricula for different school levels (primary/secondary/vocational schools) and various disciplines (including English, German, Art, Philosophy, Biology and Mathematics).

The course lasted for 14 weeks and had a specific focus on the international perspective of the concept of digital competence, and the educational use of technologies and media in the context of schools. The key elements and the basis for work within the course - both as core knowledge and as skills to be developed - were the European frameworks for digital competence for citizens (Vuorikari, Punie, Carretero, \& Brande, 2016), and for educators (Redecker \& Punie, 2017). The main objectives of the course were to:

- Identify internationally relevant research on the topic of digital competence and the educational use of technologies in schools.

- Design and produce an innovative learning scenario for the development of digital competence for children and young people.

During the course, and as its summative assessment, pre-service teachers were asked to design an educational proposal aimed at developing their students' digital competence in one or more of their subject areas, based on a digitally enhanced pedagogical approach (e.g., flipped learning, online learning or gamification). The process to 
achieve this outcome was supported by different DBR steps throughout the whole course, with mostly on-site work, and occasional remote work (Marín, 2020b). After defining their approach, pre-service teachers were tasked with conducting a literature review as a learning activity, which was partially supported by concept mapping; this is described in detail in the following sections.

\subsection{The learning activity and concept mapping tasks}

The learning activity consisted of searching for literature, summarising basic and relevant findings in a concept map, and evaluating another student's map. The concept map depicting an overview of the literature review and a written explanation of it were part of the educational proposal to be designed as the final course assessment.

The learning objectives of the activity were:

1. Identify meaningful theoretical and empirical scientific literature for the educational proposal.

2. Distinguish the most relevant concepts, relationships and results within the selected literature sources.

3. Develop a visual representation in the form of a concept map to illustrate the outcomes from the literature review.

4. Appraise other students' concept maps according to basic criteria (such as level of understanding and structure).

The whole learning activity was structured into three phases that included in-class as well as online work and lasted for four weeks (see Table 3).

Formative assessment of the learning activity included the evaluation of other students' concept maps in terms of their level of understanding and structure. The summative assessment was connected to the final course assessment and focused on the quality of the concept map in terms of how effective it was in reflecting the most important concepts, relationships and results of the literature review, to be included in the educational proposal.

\subsection{Methods}

A mixed methodology was applied, in which quantitative and qualitative data collection methods were used. The quantitative method involved the use of an anonymised online student questionnaire. The questionnaire included sections that were used to evaluate the pre-service teachers' experience of using concept maps during the course, on a Likert scale (1: completely disagree, to 5 : completely agree). Questions included the conceptualisation phase of the RBL activity, as well as aspects of usability and transfer of skills to their future role as teachers. The quantitative data gathered from the questionnaire was analysed by exploring descriptive statistics using SPSS version 26.

The qualitative method included analysis of the open answers in the student questionnaire and evaluation of the semantic aspects of the concept maps. Since the text field for open answers was optional, not all the pre-service teachers completed it, and in some cases the text provided was very short. This represents a limitation of the analysis concerning the qualitative data items. The data analysis was done using thematic analysis (Braun \& Clarke, 2006): first in a deductive manner based on the items in the quantitative part of the questionnaire, and secondly in an inductive manner in order to identify themes within the data.

The qualitative analysis of the semantic aspects of the concept maps was based on the validated rubric developed by Prats and Salinas (2018), after completing translation 
Table 3. Activity phases and learning tasks in compiling the literature review and concept maps.

\begin{tabular}{|c|c|}
\hline Activity phases & Learning tasks \\
\hline $\begin{array}{l}\text { 1. Literature search and review } \\
\text { on digital competence in } \\
\text { schools (in class - one } \\
\text { session) }\end{array}$ & $\begin{array}{l}\text { (CG) Review previous session and activity. Instructor explains literature } \\
\text { search (databases, definition of terms, and operators for the search). } \\
\text { (I/P) Define search keywords and start searching in the university } \\
\text { databases. Instructor guides in the search on an individual basis. } \\
\text { (CG) Sum up the session, brief round of evaluating the search } \\
\text { process, and discussion of difficulties and doubts. }\end{array}$ \\
\hline $\begin{array}{l}\text { 2. Literature review with } \\
\text { concept maps (introduction) (in } \\
\text { class - one session) }\end{array}$ & $\begin{array}{l}\text { (CG) Review previous session and activity. Instructor explains concept } \\
\text { maps (definition, structure, construction). } \\
\text { (I) Create a first version of a concept map using Cmap to represent the } \\
\text { literature review for the proposal (characteristics of the approach and } \\
\text { advantages and disadvantages of use in education, especially in } \\
\text { school contexts and own subject field). Instructor guides in the } \\
\text { construction of the concept map on an individual basis. } \\
\text { (CG) Sum up the session and revise the first versions of concept } \\
\text { maps. }\end{array}$ \\
\hline $\begin{array}{l}\text { 3. Literature review with } \\
\text { concept maps and peer review } \\
\text { (online - two weeks) }\end{array}$ & $\begin{array}{l}\text { (I) Create an improved version of the concept map to represent the } \\
\text { literature review for the proposal. } \\
\text { (I) Upload the concept map to the specified task in the institutional } \\
\text { virtual learning environment for a first review from another student. } \\
\text { Instructor organises the pairings of the assignments for the peer } \\
\text { review and establishes basic rubric criteria based on Prats and } \\
\text { Salinas ( } 2018 \text { ) (see Appendix A). } \\
\text { (I) Evaluate the structure of another student's concept map following a } \\
\text { simple rubric (poor, ok, good) with different criteria than in the } \\
\text { previous task. Include some brief constructive feedback for the last } \\
\text { item (general feedback). The instructor also provides feedback for } \\
\text { each concept map. }\end{array}$ \\
\hline
\end{tabular}

Key: $C G=$ in the class group, $\mathrm{I}=$ individually, $\mathrm{P}=$ in pairs

Note: the digitally enhanced pedagogical approach made it possible to work in pairs for the literature search, but each student was tasked with developing their own concept map.

and adaptations for the current learning activity (see Appendix B for the translation of the original rubric). The adaptation for this study included deleting three of the secondary evaluation criteria that were not applicable, namely the convergence with an expert map ${ }^{1}$ (one was not provided to the pre-service teachers in this instance), the quality of linked concept maps, and the quality of the examples (these two aspects were not a requirement for the task). The adapted rubric also simplified the description of the evaluation criteria related to the "quality of the resources". The original rubric included evaluation of the quality of the resources based on the diversity of sources and their association to the concept. The adapted rubric considered only whether the resources that were used were adequately connected to the concept map - there were no specific requirements regarding diversity of sources. The distinction between a grade of "very good" and one of "good" lay in how closely the resources used were related to the focus question and whether or not it was directly answered through the map. A score of zero for this evaluation criterion meant that no resources were attached. Since this was not a generalised application of the instrument, and it was applied instead to a small sample specific to the requirements of this study, no weights were applied. This was done in order to facilitate comparison between results of the various evaluation criteria, as recommended by the authors of the rubric. Limitations of this method are subjectivity when applying the rubric, and the need for expertise in the subject matter in order to use it effectively.

\footnotetext{
${ }^{1}$ An expert (skelelon) map is a concept map prepared by an expert on the topic and that serves as a guide or scaffold of students' learning (Novak \& Cañas, 2008)
} 
Ethical issues were addressed by explaining the research goals to the participants, asking for their voluntary participation in the questionnaire, and making it clear that their participation would neither be connected to the evaluation nor used for any purposes other than the current study. Voluntary written consent was also obtained from the pre-service teachers to use their concept maps for research purposes.

\section{ANALYSIS AND RESULTS}

This section presents the results of the study with regards to the main research question, which concerns the enhancement of the conceptualisation phase (of a literature review) of the RBL process through the use of concept maps in pre-service teacher education.

Eight completed student perceptions' questionnaires were obtained out of a possible ten. At first glance, the descriptive statistics for this data shows overall agreement with the positive statements posed (see Table 4). These statements concerned the first two research sub-questions, namely: what do pre-service teachers believe are the most valued uses of concept maps for literature reviews, and how do they perceive the usability and know-how transfer of concept maps?

Table 4. Quantitative results of the pre-service teacher questionnaire.

\begin{tabular}{|c|c|c|c|}
\hline & Statements & Median & SD \\
\hline \multirow{6}{*}{$\begin{array}{l}\text { Conceptualisation } \\
\text { phase of RBL: Creating } \\
\text { a concept map on the } \\
\text { literature review of my } \\
\text { proposal... }\end{array}$} & $\begin{array}{l}\text {...helped me to structure and organise the main } \\
\text { concepts and their relationships related to my } \\
\text { topic. }\end{array}$ & 4.00 & 0.835 \\
\hline & $\begin{array}{l}\text {...was helpful to summarise the literature } \\
\text { findings related to my topic. }\end{array}$ & 3.50 & 0.535 \\
\hline & $\begin{array}{l}\text {...helped me to clearly visualise the overview of } \\
\text { experiences and concepts related to my topic. }\end{array}$ & 3.50 & 0.926 \\
\hline & $\begin{array}{l}\text {...involved a deep understanding of the literature } \\
\text { related to my topic from my side. }\end{array}$ & 3.00 & 0.926 \\
\hline & $\begin{array}{l}\text {...made me reflect deeper on my topic than if } \\
\text { I had to write about it. }\end{array}$ & 3.50 & 0.744 \\
\hline & I found that concept maps are easy to create. & 3.50 & 0.535 \\
\hline \multirow{4}{*}{$\begin{array}{l}\text { Usability and know-how } \\
\text { transfer }\end{array}$} & $\begin{array}{l}\text { I found that concept maps are a good tool for } \\
\text { summarising a small-scale literature review. }\end{array}$ & 4.00 & 0.535 \\
\hline & $\begin{array}{l}\text { I found that concept maps are a good tool in } \\
\text { teacher education. }\end{array}$ & 4.00 & 0.463 \\
\hline & $\begin{array}{l}\text { I can imagine using concept maps in my } \\
\text { professional context in the future. }\end{array}$ & 4.00 & 0.535 \\
\hline & $\begin{array}{l}\text { I can imagine using concept maps for } \\
\text { pedagogical purposes with my future students. }\end{array}$ & 4.00 & 0.354 \\
\hline
\end{tabular}

Note: due to the small number of answers and high response variation in some of the items, the medians are included to better reflect the broader opinion, instead of the average means.

In the case of statements regarding the conceptualisation phase of RBL, pre-service teachers most appreciated the value of concept maps for structuring and organising their literature reviews $(\mathrm{Me}=4.00)$. The lowest value (neutral) corresponds with concept maps invoking a deeper understanding of the literature $(\mathrm{Me}=3.00)$. With an overall lower variation among responses, pre-service teachers agreed on the benefits of usability and know-how transfer of concept maps for them as future teachers. The lowest value for the pre-service teachers was the ease of creating concept maps $(\mathrm{Me}=$ 3.50). The remaining items yielded a higher value $(\mathrm{Me}=4.00)$. 
In line with the previous results concerning the usefulness of concept maps for helping to build structure and to get an overview, some pre-service teachers expressed a positive opinion in the open text field of the questionnaire, showing different views regarding the ease of creating concept maps:

"It helped me to get an overview and structure. It wasn't easy to create; I think it is quite difficult to connect everything correctly."

"Clean overview - fairly easy to utilize."

The need for synthesis in a concept map was mentioned by another pre-service teacher:

"It's certainly a useful tool to get acquainted with since it's very basic but nearly universally applicable. The nature of it (few words per concept and single-word connectors) can be frustrating for people who prefer to explain, but it has the advantage of brevity."

Finally, another comment referred to the novelty of the method and tool, which brought enjoyment to this student:

"It was certainly something new and innovative that I enjoyed doing."

The third research sub-question addressed the semantic quality of the pre-service teachers' concept maps in representing their literature reviews. The qualitative analysis through the application of the rubric described in the Methods section of the six concept maps (CM) for which written consent forms were obtained is presented in Table 5.

Table 5. Results of the evaluation of the concept maps according to semantic aspects (based on the evaluation criteria in Annex 2, scores: 0 Poor - 3 Very good).

\begin{tabular}{llllllll}
\hline $\begin{array}{l}\text { Evaluation } \\
\text { criteria }\end{array}$ & $\begin{array}{l}\text { Focus } \\
\text { question }\end{array}$ & $\begin{array}{l}\text { Main } \\
\text { concept }\end{array}$ & $\begin{array}{l}\text { Complexity } \\
\text { of the } \\
\text { concepts }\end{array}$ & $\begin{array}{l}\text { Quality of } \\
\text { the link } \\
\text { phrases }\end{array}$ & $\begin{array}{l}\text { Proposition Quality of } \\
\text { as a unit } \\
\text { of } \\
\text { meaning }\end{array}$ & $\begin{array}{l}\text { Total } \\
\text { the } \\
\text { resources }\end{array}$ & (average) \\
\hline CM01 & 3 & 2 & 2 & 3 & 3 & 3 & 2.7 \\
CM02 & 2 & 3 & 2 & 2 & 1 & 0 & 1.7 \\
CM03 & 2 & 3 & 2 & 3 & 2 & 0 & 2 \\
CM04 & 1 & 2 & 1 & 0 & 0 & 2 & 1 \\
CM05 & 3 & 3 & 2 & 3 & 2 & 3 & 2.7 \\
CM06 & 3 & 3 & 2 & 3 & 2 & 3 & 2.7 \\
\hline
\end{tabular}

The results of the analysis of the maps show that for most of the pre-service teachers (five out of the six evaluated maps), the concept maps were of a high quality in terms of representing the literature reviews, at least to the degree that was expected in the course. An example of a concept map representing a small-scale literature review by one of the pre-service teachers is presented in Figure 1.

Some considerations should be made in order to fully understand the evaluation of certain criteria related to the semantic quality of the concept maps. Regarding the criteria "focus question", although not all the pre-service teachers presented the focus question within their concept maps, they were provided with a basic question that they were tasked with adapting to each of their topics. This basic question had two parts: to define or present their topic as a concept, and to show the educational applications of 


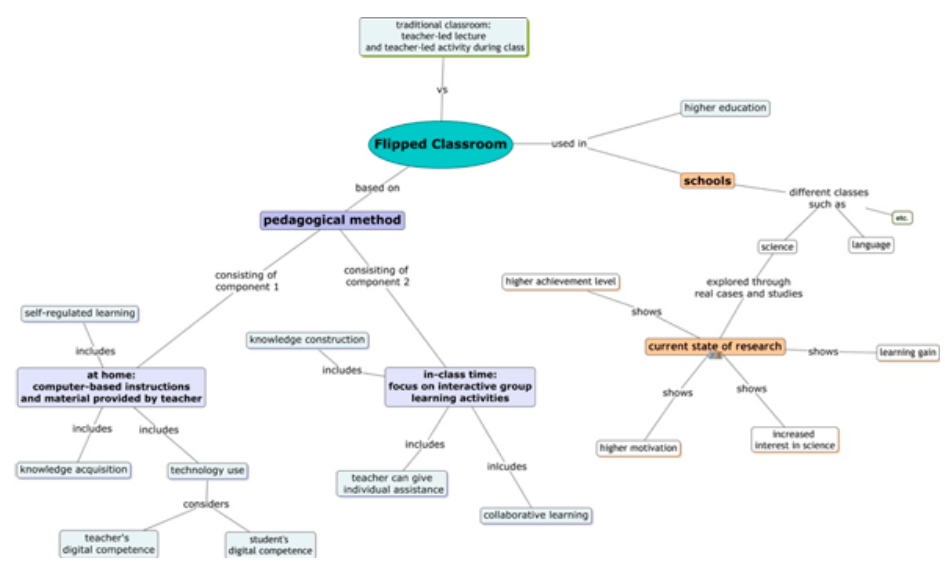

Figure 1. Overview of the literature review on flipped classroom in the concept map CM06.

that topic, preferably in the school context and their subject field. They were required to address both question parts based on literature that they found before the activity phases with concept maps.

With regard to the complexity of the concepts presented, it is important to note that the literature review was specifically required to be a small-scale search and the concept map was only one part of that task, fitting broadly within the final educational proposal. Furthermore, none of the pre-service teachers had conducted a literature review or used concept maps before, so it is understandable that there are several opportunities to improve in complexity, such as enabling longer literature review periods and more frequent use of concept maps. Three of the pre-service teachers performed some of the so-called "secondary functions" of concept maps according to the evaluation rubric - that is, the inclusion of examples in the maps and the creation of a nested concept map, which is a variation of a linked concept map. These activities were not directly specified in the task, nor were they considered in the analysis.

\section{DISCUSSION AND CONCLUSIONS}

This study aimed to investigate how the conceptualisation phase (of a literature review) within an RBL process may be supported through the use of digital concept maps in pre-service teacher education. The topic of using digital tools such as concept maps in this context - RBL and pre-service teacher education - has not been previously explored. The contribution that this paper makes to the literature is mainly empirical and related to teacher education practice. The study sheds light on higher education practice and provides recommendations and guidelines for both practice and further research.

The results of this study suggest that digital concept maps are a suitable tool for supporting the type of small-scale literature review that was expected in the pre-service teacher education course in this study. The pre-service teachers produced good quality overviews in the form of a concept map for their literature reviews. Furthermore, they valued the use of digital concept maps most in terms of structuring and organising the main concepts and relationships connected to their topics, which is in line with the findings of Koc (2012). Other benefits that were moderately valued were summarising the literature findings, clearly visualising the overview of experiences and concepts related to the topic and reflecting on the topic.

Despite finding differences in perceptions of the ease of creating concept maps which is common in other studies (Koc, 2012) -, overall pre-service teachers appreciated the usability and know-how transfer of concept maps for their professional 
future as teachers, which is also in line with previous studies (Pedrajas, 2012). This is especially relevant considering a) the pedagogical benefits in school contexts of concept maps (Kinchin, 2000; Nesbit \& Adesope, 2006; Prats \& Ferrer, 2012); and b) the importance of digital competence of educators and younger students (Redecker \& Punie, 2017; Vuorikari et al., 2016). Concept maps may be considered as part of the area of content creation as a citizen/young student (EU DigComp2.0 framework) by promoting meaningful learning (Kinchin, 2014); and in terms of pedagogical competences they provide a focus on creating digital resources and applying teaching and learning methods that embed concept mapping in the practice of an educator (Vuorikari et al., 2016).

This study offers the following recommendations to support the conceptualisation phase of RBL with digital concept maps in pre-service teacher education (see Table 6).

Table 6. Recommendations for practice: using concept maps for a literature review in pre-service teacher education.

\begin{tabular}{|c|c|c|c|}
\hline & $\begin{array}{l}\text { Before the concept map } \\
\text { activity }\end{array}$ & $\begin{array}{l}\text { During the concept map } \\
\text { activity }\end{array}$ & $\begin{array}{l}\text { After the concept map } \\
\text { activity }\end{array}$ \\
\hline $\begin{array}{l}\text { Use of concept } \\
\text { maps }\end{array}$ & $\begin{array}{l}\text { Support pre-service } \\
\text { teachers to get familiar with } \\
\text { the structure of concept } \\
\text { maps and the differences } \\
\text { from mind maps. Students } \\
\text { may have experience in } \\
\text { mind maps but are unlikely } \\
\text { to have heard of concept } \\
\text { maps. }\end{array}$ & $\begin{array}{l}\text { Offer on-site and remote } \\
\text { support for the } \\
\text { development of the } \\
\text { concept map. For } \\
\text { instance, the Cmap } \\
\text { website offers } \\
\text { documentation in text } \\
\text { and video format that } \\
\text { could be used as } \\
\text { support material. }\end{array}$ & $\begin{array}{l}\text { Peer reviewing of basic } \\
\text { aspects (such as } \\
\text { structure) is a good way } \\
\text { to boost } \\
\text { self-assessment of } \\
\text { concept maps among } \\
\text { pre-service teachers. }\end{array}$ \\
\hline Literature review & $\begin{array}{l}\text { Literature to be } \\
\text { summarised in the map } \\
\text { should be selected by the } \\
\text { pre-service teachers in } \\
\text { advance. Depending on the } \\
\text { degree of complexity, the } \\
\text { number of papers to be } \\
\text { summarised in the concept } \\
\text { map could vary. However, it } \\
\text { is better to have only two } \\
\text { papers connected to a } \\
\text { specific concept, rather } \\
\text { than many that do not cover } \\
\text { the topic sufficiently. Advise } \\
\text { the pre-service teachers to } \\
\text { explore further literature by } \\
\text { using linked or nested } \\
\text { concept maps (thereby } \\
\text { utilising other digital } \\
\text { possibilities). }\end{array}$ & $\begin{array}{l}\text { Literature should be } \\
\text { attached as a resource } \\
\text { in the form of } \\
\text { documents or links to } \\
\text { the relevant concept } \\
\text { (another potencial of the } \\
\text { digital). This makes it } \\
\text { clear how the map has } \\
\text { been built and how } \\
\text { pre-service teachers } \\
\text { have understood the } \\
\text { literature connected to } \\
\text { their topic., }\end{array}$ & $\begin{array}{l}\text { Provide feedback on } \\
\text { the structure and } \\
\text { content of the concept } \\
\text { map with regard to the } \\
\text { appropriateness of the } \\
\text { literature review. The } \\
\text { structure of the } \\
\text { concept map may be } \\
\text { verified through } \\
\text { complete propositions } \\
\text { and connection to the } \\
\text { focus question and to } \\
\text { the main concept. For } \\
\text { content evaluation, the } \\
\text { university instructor } \\
\text { should have sufficient } \\
\text { expertise on the topic. } \\
\text { For both structure and } \\
\text { content, rubrics should } \\
\text { be available (e.g. in } \\
\text { Appendices A and B ). }\end{array}$ \\
\hline Research question & $\begin{array}{l}\text { Based on the previous } \\
\text { literature review, pre-service } \\
\text { teachers should define or } \\
\text { adapt a focus question to } \\
\text { be addressed in their } \\
\text { concept maps. }\end{array}$ & $\begin{array}{l}\text { Pre-service teachers } \\
\text { should construct a } \\
\text { concept map based on a } \\
\text { focus question that they } \\
\text { have defined or adapted, } \\
\text { clearly marked at the top } \\
\text { of the map. The map } \\
\text { should answer that } \\
\text { question through the } \\
\text { literature review. }\end{array}$ & $\begin{array}{l}\text { Pre-service teachers } \\
\text { should use the concept } \\
\text { map to connect theory } \\
\text { and practice (DBR), by } \\
\text { connecting the } \\
\text { literature review in the } \\
\text { map to the educational } \\
\text { proposal or innovation } \\
\text { that they plan to } \\
\text { prepare. }\end{array}$ \\
\hline
\end{tabular}


These guidelines and recommendations may be useful for other higher education contexts outside pre-service teacher education, and for paper-based concept mapping activities.

The major limitation of the study is the small and purposeful sample, which meant that there was a small data set for analysis. Further studies should consider bigger samples and wider contexts to reduce this possible bias and include more in-depth qualitative methods to collect further information (e.g., interviews, focus groups).

Future research should consider the use of digital concept maps for other RBL processes - apart from the conceptualisation phase - in pre-service teacher education, such as the ones proposed by Marin (2019). These include orientation (brainstorming a topic or problem statement), investigation (developing the research design and data collection), conclusion and discussion (communication and reflection).

\section{A. APPENDIX}

Rubric criteria for peer review of the concept maps in the institutional virtual learning environment

- Inclusion of concrete and clear concepts (instead of text fragments or sentences)

- Existence of relationships between concepts (linking words, verbs, propositions)

- Degree of ramification (a concept or linking word has two or more connection lines)

- Depth in the hierarchy (high number of links between the main concept and the farthest one)

- Existence of cross-links (relationships between concepts in different segments of the concept map)

- Inclusion of resources associated to some concepts (links, documents, etc.)

- General feedback

(Rating for each of the criteria: weak, ok, good)

\section{B. APPENDIX}

Original validated rubric to evaluate concept maps according to semantic aspects.

\begin{tabular}{|c|c|c|c|c|c|c|}
\hline Type & $\begin{array}{l}\text { Evaluation } \\
\text { criteria }\end{array}$ & Very good (3) & Good (2) & Average (1) & Poor (0) & Weight \\
\hline Basic & $\begin{array}{l}\text { Focus } \\
\text { question }\end{array}$ & $\begin{array}{l}\text { All the } \\
\text { aspects of the } \\
\text { focus } \\
\text { question are } \\
\text { addressed in } \\
\text { the concept } \\
\text { map. }\end{array}$ & $\begin{array}{l}\text { Most of the } \\
\text { aspects of } \\
\text { the focus } \\
\text { questions } \\
\text { are } \\
\text { addressed } \\
\text { in the } \\
\text { concept } \\
\text { map. }\end{array}$ & $\begin{array}{l}\text { The } \\
\text { concept } \\
\text { map only } \\
\text { partially } \\
\text { answers } \\
\text { the focus } \\
\text { question. }\end{array}$ & $\begin{array}{l}\text { The focus } \\
\text { question } \\
\text { does not } \\
\text { exist, or } \\
\text { the concept } \\
\text { map does } \\
\text { not answer } \\
\text { it. }\end{array}$ & 8 \\
\hline
\end{tabular}




\begin{tabular}{|c|c|c|c|c|c|c|}
\hline \multicolumn{7}{|c|}{ Table 7 continued } \\
\hline Type & $\begin{array}{l}\text { Evaluation } \\
\text { criteria }\end{array}$ & Very good (3) & Good (2) & Average (1) & Poor (0) & Weight \\
\hline Basic & $\begin{array}{l}\text { Main } \\
\text { concept }\end{array}$ & $\begin{array}{l}\text { The main } \\
\text { concept is } \\
\text { related to all } \\
\text { the other } \\
\text { concepts in } \\
\text { the map. }\end{array}$ & $\begin{array}{l}\text { More than } \\
\text { half of the } \\
\text { concepts } \\
\text { are related } \\
\text { to the main } \\
\text { concept. }\end{array}$ & $\begin{array}{l}\text { Only a few } \\
\text { concepts } \\
\text { have a } \\
\text { relationship } \\
\text { with the } \\
\text { main } \\
\text { concept. }\end{array}$ & $\begin{array}{l}\text { It is not } \\
\text { clear what } \\
\text { the main } \\
\text { concept is. }\end{array}$ & 8 \\
\hline Basic & $\begin{array}{l}\text { Complexity } \\
\text { of the } \\
\text { concepts }\end{array}$ & $\begin{array}{l}\text { All the } \\
\text { concepts are } \\
\text { relevant, and } \\
\text { nothing } \\
\text { important is } \\
\text { missing. }\end{array}$ & $\begin{array}{l}\text { Predominance } \\
\text { of relevant } \\
\text { concepts, } \\
\text { but some } \\
\text { important } \\
\text { concepts } \\
\text { are } \\
\text { missing. }\end{array}$ & $\begin{array}{l}\text { Low } \\
\text { number of } \\
\text { relevant } \\
\text { concepts. }\end{array}$ & $\begin{array}{l}\text { There are } \\
\text { no relevant } \\
\text { concepts. }\end{array}$ & 7 \\
\hline Basic & $\begin{array}{l}\text { Quality of } \\
\text { the link } \\
\text { phrases }\end{array}$ & $\begin{array}{l}\text { All the link } \\
\text { phrases are } \\
\text { formed by } \\
\text { more than } \\
\text { one word and } \\
\text { give meaning } \\
\text { to the } \\
\text { proposition. }\end{array}$ & $\begin{array}{l}\text { Phrases of } \\
\text { more than } \\
\text { one word } \\
\text { are } \\
\text { combined } \\
\text { with others } \\
\text { of higher } \\
\text { complexity } \\
\text { (two or } \\
\text { more } \\
\text { words). }\end{array}$ & $\begin{array}{l}\text { All the link } \\
\text { phrases } \\
\text { are one } \\
\text { word and } \\
\text { are of } \\
\text { minor } \\
\text { importance. }\end{array}$ & $\begin{array}{l}\text { There are } \\
\text { no link } \\
\text { phrases. }\end{array}$ & 8 \\
\hline Basic & $\begin{array}{l}\text { The } \\
\text { proposition } \\
\text { as a unit of } \\
\text { meaning }\end{array}$ & $\begin{array}{l}\text { All the } \\
\text { propositions } \\
\text { are well } \\
\text { structured. }\end{array}$ & $\begin{array}{l}\text { At least } \\
\text { half of the } \\
\text { propositions } \\
\text { are well } \\
\text { structured. }\end{array}$ & $\begin{array}{l}\text { There are } \\
\text { few well- } \\
\text { structured } \\
\text { propositions. }\end{array}$ & $\begin{array}{l}\text { There are } \\
\text { no well- } \\
\text { structured } \\
\text { propositions. }\end{array}$ & 10 \\
\hline Secondary & $\begin{array}{l}\text { Convergence } \\
\text { with the } \\
\text { expert map }\end{array}$ & $\begin{array}{l}\text { The map } \\
\text { presents } \\
\text { fewer than } 5 \\
\text { differences } \\
\text { from the } \\
\text { expert map. }\end{array}$ & $\begin{array}{l}\text { The map } \\
\text { presents } \\
\text { between } 5 \\
\text { and } 10 \\
\text { differences } \\
\text { from the } \\
\text { expert } \\
\text { map. }\end{array}$ & $\begin{array}{l}\text { The map } \\
\text { presents } \\
\text { between } 11 \\
\text { and } 19 \\
\text { differences } \\
\text { from the } \\
\text { expert } \\
\text { map. }\end{array}$ & $\begin{array}{l}\text { The map } \\
\text { presents } \\
\text { more than } \\
20 \\
\text { differences } \\
\text { from the } \\
\text { expert } \\
\text { map. }\end{array}$ & 8 \\
\hline Secondary & $\begin{array}{l}\text { Validity of } \\
\text { the } \\
\text { examples } \\
\text { presented }\end{array}$ & $\begin{array}{l}\text { At least } 75 \% \\
\text { of the } \\
\text { examples are } \\
\text { valid. }\end{array}$ & $\begin{array}{l}\text { At least } \\
50 \% \text { of the } \\
\text { examples } \\
\text { are valid. }\end{array}$ & $\begin{array}{l}\text { At least } \\
25 \% \text { of the } \\
\text { examples } \\
\text { are valid. }\end{array}$ & $\begin{array}{l}\text { None of the } \\
\text { examples } \\
\text { are valid. }\end{array}$ & 8 \\
\hline Secondary & $\begin{array}{l}\text { Quality of } \\
\text { the } \\
\text { resources }\end{array}$ & $\begin{array}{l}\text { The resources } \\
\text { are of varied } \\
\text { typology and } \\
\text { are all } \\
\text { relevant to the } \\
\text { concept with } \\
\text { which they are } \\
\text { associated. }\end{array}$ & $\begin{array}{l}\text { The } \\
\text { resources } \\
\text { are of } \\
\text { varied } \\
\text { typology } \\
\text { and half of } \\
\text { them are } \\
\text { relevant to } \\
\text { the concept } \\
\text { with which } \\
\text { they are } \\
\text { associated. }\end{array}$ & $\begin{array}{l}\text { The } \\
\text { resources } \\
\text { associated } \\
\text { with the } \\
\text { concept are } \\
\text { scarce. }\end{array}$ & $\begin{array}{l}\text { The } \\
\text { resources } \\
\text { are not } \\
\text { relevant to } \\
\text { the concept } \\
\text { with which } \\
\text { they are } \\
\text { associated. }\end{array}$ & 8 \\
\hline
\end{tabular}




\begin{tabular}{|c|c|c|c|c|c|c|}
\hline \multicolumn{7}{|c|}{ Table 7 continued } \\
\hline Type & $\begin{array}{l}\text { Evaluation } \\
\text { criteria }\end{array}$ & Very good (3) & Good (2) & Average (1) & Poor (0) & Weight \\
\hline Secondary & $\begin{array}{l}\text { Quality of } \\
\text { linked } \\
\text { concept } \\
\text { maps }\end{array}$ & $\begin{array}{l}\text { The linked } \\
\text { concept maps } \\
\text { are } \\
\text { meaningful } \\
\text { and form a } \\
\text { knowledge } \\
\text { model. }\end{array}$ & $\begin{array}{l}\text { Some of } \\
\text { the aspects } \\
\text { of the } \\
\text { linked } \\
\text { concept } \\
\text { maps are } \\
\text { meaningful } \\
\text { with } \\
\text { respect to } \\
\text { the main } \\
\text { map. }\end{array}$ & $\begin{array}{l}\text { The linked } \\
\text { concept } \\
\text { maps do } \\
\text { not provide } \\
\text { meaningful } \\
\text { connections } \\
\text { to the main } \\
\text { map. }\end{array}$ & $\begin{array}{l}\text { There are } \\
\text { no linked } \\
\text { concept } \\
\text { maps. }\end{array}$ & 10 \\
\hline
\end{tabular}

\section{REFERENCES}

Aditomo, A., Goodyear, P., Bliuc, A. M., \& Ellis, R. A. (2013). Inquiry-based learning in higher education: principal forms, educational objectives, and disciplinary variations. Studies in Higher Education, 38(9), 1239-1258. https://doi.org/10.1080/03075079.2011.616584

Agudelo, O. L., \& Salinas, J. (2015). Flexible Learning Itineraries Based on Conceptual Maps. Journal of New Approaches in Educational Research, 4(2), 70-76. https://doi.org/10.7821/ naer.2015.7.130

Berry, J. W., \& Chew, S. L. (2008). Improving Learning through Interventions of StudentGenerated Questions and Concept Maps. Teaching of Psychology, 35(4), 305-312. https://doi.org/10.1080/00986280802373841

Beyerbach, B. A., \& Smith, J. M. (1990). Using a computerized concept mapping program to assess preservice teachers' thinking about effective teaching. Fournal of Research in Science Teaching, 27(10), 961-971. https://doi.org/10.1002/tea.3660271005

Braun, V., \& Clarke, V. (2006). Using thematic analysis in psychology. Qualitative Research in Psychology, 3(2), 77-101. https://doi.org/10.1191/1478088706qp063oa

Brew, A., \& Saunders, C. (2020). Making sense of research-based learning in teacher education. Teaching and Teacher Education, 87. https://doi.org/10.1016/j.tate.2019 102935

Buldu, M., \& Buldu, N. (2010). Concept mapping as a formative assessment in college classrooms: Measuring usefulness and student satisfaction. Procedia-Social and Behavioral Sciences, 2(2), 2099-2104. https://doi.org/10.1016/j.sbspro.2010.03.288

Darder, A., Pérez, A., \& Salinas, J. (2014, October). Análisis de usos del mapa conceptual en la investigación. Proceedings of Sixth International Conference on Concept Mapping (pp. 31-38). Santos, Brazil. https://doi.org/10.13140/2.1.3842.5609

Davies, M. (2011). Concept mapping, mind mapping and argument mapping: What are the differences and do they matter? Higher Education, 62(3), 279-301. https://doi.org/ 10.1007/s10734-010-9387-6

de Benito, B., Lizana, A., \& Salinas, J. (2017). Using concept mapping for faculty development in the context of pedagogic frailty. Knowledge Management and E-Learning, 9(3), 329347. https://doi.org/10.34105/j.kmel.2017.09.020

de Benito, B., \& Salinas, J. (2016). La Investigación Basada en Diseño en Tecnología Educativa. Revista Interuniversitaria de Investigación En Tecnología Educativa(0), 4459. http://dx.doi.org/10.6018/riite2016/260631

Easterday, M. W., Lewis, D. G. R., \& Gerber, E. M. (2018). The logic of design research. Learning: Research and Practice, 4(2), 131-160. https://doi.org/10.1080/23735082.2017 1286367

Hay, D., \& Kinchin, I. M. (2008). Using concept mapping to measure learning quality. Education and Training, 50(2), 167-182. https://doi.org/10.1108/00400910810862146 
Kinchin, I. M. (2000). Concept mapping in biology. Journal of Biological Education, 34(2), 61-68. https://doi.org/10.1080/00219266.2000.9655687

Kinchin, I. M. (2014). Concept Mapping as a Learning Tool in Higher Education: A Critical Analysis of Recent Reviews. The fournal of Continuing Higher Education, 62(1), 39-49. https://doi.org/10.1080/07377363.2014.872011

Koc, M. (2012). Pedagogical knowledge representation through concept mapping as a study and collaboration tool in teacher education. Australasian fournal of Educational Technology, 28(4), 656-670. https://doi.org/10.14742/ajet.833

Lizana, A., Marín, V. I., Moreno, J., Paniza, S., \& Salinas, J. (2014). Diseño, desarrollo y validación de un prototipo de material multimedia en formación ocupacional. In P. R. M. Correia, M. E. I. Malachias, A. J. Cañas, \& J. D. Novak (Series Eds.), 2. Concept Mapping to Learn and Innovate. Proceedings of Sixth International Conference on Concept Mapping (Vol. 1, pp. 225-232). Santos, Brazil: University of Sao Paulo, Institute for Human and Machine Cognition.

Marín, V. I. (2019). Research-based Learning enhanced by Technology in Higher Education: a Comparative Analysis of Tools. In E. Vaquero, E. Brescó, J. Coidures, \& F. X. Carrera (Eds.), EDUcación con TECnología: un compromiso social. Iniciativas y resultados de investigaciones y experiencias de innovación educativa (pp. 459-471). Palma de Mallorca: Edicions de la Universitat de Lleida/Asociación EDUTEC.

Marín, V. I. (2020a). Research-based learning in education studies: Design inquiry using group e-Portfolios based on blogs. Australasian fournal of Educational Technology, 36(1), 1-20. https://doi.org/10.14742/ajet.4523

Marín, V. I. (2020b). Technology-enhanced Learning Design of a Pre-service Teacher Training Course in a Research-based Learning context. Universitas Tarraconensis. Revista de Ciències de l'Educació., 1(3), 14-26.

Marín, V. I., \& Schirmer, C. (2018). Design of a teacher-training workshop to support research-based learning processes with digital media. In N. Neuber, W. Paravicini, \& M. Stein (Eds.), Forschendes Lernen. The Wider View. Eine Tagung des Zentrums für Lehrerbildung der Westfälischen Wilhelms-Universität Münster vom 25. bis 27.09.2017. Schriften zur Allgemeinen Hochschuldidaktik. Band 3 (pp. 99-111). Münster: WTMVerlag.

Mor, Y., \& Mogilevsky, O. (2013). Learning Design Studio: Educational Practice as Design Inquiry of Learning. In D. Hernández-Leo, R. Klamma, \& A. Harrer (Eds.), Scaling up Learning for Sustained Impact. EC-TEL 2013. Lecture Notes in Computer Science (Vol. 8095, pp. 233-245). Berlin: Springer. https://doi.org/10.1007/978-3-642-40814-4_19

Mor, Y., \& Mogilevsky, O. (2013 b). The learning design studio: Collaborative design inquiry as teachers' professional development. Research in Learning Technology, 21.

Nesbit, J. C., \& Adesope, O. O. (2006). Learning With Concept and Knowledge Maps: A Meta-Analysis. Review of Educational Research, 76(3), 413-448. https://doi.org/10.3102/ 00346543076003413

Novak, J. D., \& Cañas, A. J. (2006). The Origins of the Concept Mapping Tool and the Continuing Evolution of the Tool. Information Visualization, 5(3), 175-184. https:// doi.org/10.1057/palgrave.ivs.9500126

Novak, J. D., \& Cañas, A. J. (2008). The theory underlying concept maps and how to construct and use them. Retrieved from https://web.stanford.edu/dept/SUSE/projects/ireport/ articles/concept_maps/The\%20Theory\%20Underlying\%20Concept\%20Maps.pdf

Pedrajas, A. P. (2012). Representación y comunicación del conocimiento con mapas conceptuales en la formación del profesorado de ciencia y tecnología. Revista Eureka sobre enseñanza y divulgación de las ciencias, 9(1), 106-123. Retrieved from http:// hdl.handle.net/10498/14628 https://doi.org/10.25267/rev_eureka_ensen_divulg_cienc .2012.v9.11.08

Prats, E., \& Ferrer, I. (2012). Los mapas conceptuales como elemento para mejorar la comprensión de textos. Una experiencia en educación primaria. In A. J. Cañas, 
J. D. Novak, \& J. Vanhear (Eds.), Concept Maps: Theory, Methodology, Technology Proc. of the Fifth Int. Conference on Concept Mapping. Valletta: Malta: IHMC. Retrieved from http://cmc.ihmc.us/cmc2012Papers/cmc2012-p111.pdf

Prats, E., \& Salinas, J. (2018). Evaluación de mapas conceptuales a partir de una doble rúbrica. Concept Mapping: Renewing Learning and Thinking. Proc. of the Eighth Int. Conference on Concept Mapping. Medellin: Colombia.

Redecker, C., \& Punie, Y. (2017). European Framework for the Digital Competence of Educators: DigCompEdu. Foint Research Centre (FRC) Science for Policy report. https://doi.org/10.2760/159770

Reinmann, G. (2018). Reader zu Design-Based Research. Hamburg. Retrieved from https:// gabi-reinmann.de/wp-content/uploads/2018/06/Reader_DBR_Juni2018.pdf

Rijst, R. V. D. (2017). The Transformative Nature of Research-Based Education: A Thematic Overview of the Literature. In E. Bastiaens, J. van Tilburg, \& J. van Merriënboer (Eds.), Research-Based Learning: Case Studies from Maastricht University. Professional Learning and Development in Schools and Higher Education (Vol. 15, pp. 3-22). Cham: Springer. https://doi.org/10.1007/978-3-319-50993-8_1

Rueß, J., Gess, C., \& Deicke, W. (2016). Forschendes Lernen und forschungsbezogene Lehre - empirisch gestützte Systematisierung des Forschungsbezugs hochschulischer Lehre. Zeitschrift für Hochschulentwicklung, 11(2), 23-44. Retrieved from https://zfhe.at/index .php/zfhe/article/view/914

Saunders, C. (2017). Research Based Learning in Teacher Education at Humboldt-Universität zu Berlin . Deutsche Gesellschaft für Hochschuldidaktik (dghd) and Universität Oldenburg. Retrieved from https://uol.de/fileadmin/user_upload/lehre/flif/Homepage _neu/Working_Paper/WP-001-Saunders_FINAL.pdf

Schaal, S. (2010). Cognitive and motivational effects of digital concept maps in pre-service science teacher training. Procedia - Social and Behavioral Sciences, 2(2), 640-647. https://doi.org/10.1016/j.sbspro.2010.03.077

Tergan, S. O., \& Keller, T. (2005). Digital concept mapping in learning contexts: Integrating knowledge, arguments and information resources. Proceedings of the International Conference on Information Visualisation (pp. 371-376). https://doi.org/10.1109/IV.2005 .44

The-Design-Based-Research-Collective. (2003). Design-Based Research: An Emerging Paradigm for Educational Inquiry. Educational Researcher, 32(1), 5-8. https://doi.org/ 10.3102/0013189X032001005

Vuorikari, R., Punie, Y., Carretero, S., \& Brande, L. V. D. （2016). DigComp 2.0: The Digital Competence Framework for Citizens. EU Commission JRC Technical Reports. Luxembourg: Publications Office of the European Union. https://doi.org/10.2791/11517

\section{AUTHOR BIOGRAPHY}

Victoria I. Marín Senior Research Fellow (Ramón y Cajal) in Educational Sciences at the University of Lleida (Spain) and member of the research group Competences, Education, Technology and Society (COMPETECS) at the same university. She holds a $\mathrm{PhD}$ in Educational Technology from the University of the Balearic Islands (Spain). Previously she worked as Postdoctoral Researcher at the Carl von Ossietzky University of Oldenburg (Germany), which was her affiliation during this study. 